\title{
PERKAWINAN SEBAGAI SIMBOLISASI KONTROL SOSIAL TERHADAP PEREMPUAN
}

Oleh : Umi Sumbulah

\begin{abstract}
There are some marital regulation in Islam which are considered as gender bias such as the concept of wali, nusyuz, the practice of polygamy, right and obligation of the spouse. It does not only create various religious understanding which is gender bias but also create asymmetrical relation of which it results in various forms of gender inequality.In particular circumstances, children become vulnerable victims of figh as the law product of men's understanding and effort which are generated from what have been regulated in The Qur'an and Hadith under patriarchal socio-cultural and political setting. Nurture theory about social role of man and woman also contributes to marginalization and sub-ordination of woman in spouse relationship within the family.
\end{abstract}

\section{A. Pendahuluan}

Konsep pernikahan seperti didefinisikan para ulama fiqih, ditengarai memiliki implikasi besar terhadap bangunan rumah tangga yang dikonstruksi berdasarkan konsep nikah dimaksud. Hampir semua ulama memahami pernikahan sebagai perikatan kontraktual semata, yang pada intinya adalah penghalalan perilaku dan hubungan seksual. ${ }^{1}$ Konsep kepemilikan (milk) dalam perikatan pernikahan, baik milk al-raqabah (memiliki sesuatu secara keseluruhan seperti kepemilikan terhadap benda dengan jalan jual beli), milk al-manfa'at (memiliki kemanfaatan suatu benda dengan cara menyewa) maupun milk al-intifa'( memiliki penggunaan sesuatu tanpa orang lain berhak menggunakannya) mengacu kepada perilaku seksualitas dimaksud.

Manusia sebagai makhluk Tuhan yang dilengkapi rasa cinta terhadap lain jenis selaku makhluk biologis dan memiliki hasrat serta minat untuk mengembangkan keturunan sebagai tunas atau generasi penerus yang akan melanjutkan garis keturunan. Namun di samping fungsinya sebagai penerus

\footnotetext{
${ }^{1}$ Abdurrahman al-Jaziri. Al-Figh 'ala madzahib al-Arba'ah. Istambul: Dar al-Da'wah, vol.IV, 2.
} 
diharapkan juga menjadi generasi pelurus (generasi yang saleh) yang akan mampu menyeru manusia kepada kema'rufan dan mencegah manusia dari memunkaran. Untuk mengatur sesuanya di atas Islam memberikan sarana sebagai fasilitator yaitu nikah.

Berpasangan merupakan ketetapan Ilahi untuk semua makhluk hidup sebagaimana dalam Q.S. al-Dzariyat (51): 49, Yasin (36): 36, al-Syura (42): 11, al-Rum (30): 21. Pernikahan merupakan keterikatan dua pihak yang dilandasi mawaddah (cinta yang penuh kelapangan terhadap kekurangan pasangannya sebagai bagian hidupnya), rahmah (kasih sayang dengan perasaan saling memiliki sebagai pilihan yang terbaik), dan sakinah (ketenangan, ketentraman, kekompakan, harmonis dan terbuka). Dalam al-Qur'an pernikahan adalah status suami istri yang diikat dalam ijab-qabul dianggap merupakan perjanjian yang kokoh antara dua manusia, misaqan galizan. ${ }^{2}$

Hukum pernikahan menurut Jumhur ulama adalah sunnah. Ulama Dhahiriyah menghukuminya dengan wajib. Sebagian ulama Malikiyah mengatakan bahwa hukum pernikahan ada 3: wajib (bagi orang yang tidak dapat mengendalikan nafsu), sunnah (bagi orang yang menginginkannya) dan mubah (bagi orang yang tidak begitu menginginkannya). Semuanya bergantung pada ada tidaknya kemaslahatan khususnya bagi pelakunya dan umumnya bagi seluruh umat manusia. ${ }^{3}$

Atas dasar hadis di atas, kaum muslim Indonesia yang mayoritas bermazhab Syafi'iyah menetapkan hukum perkawinan sebagai sunnah mu'akkadah (anjuran yang hampir mendekati kewajiban). Maka bagi mereka yang telah menginjak dewasa, baik lelaki atau perempuan penting untuk dicarikan jodoh. Dengan demikian pencatatan nikah yang sekaligus memiliki arti jaminan kepastian hukum status pernikahan dengan segala akibat yang ditimbulkannya, merupakan suatu keharusan, dan kebutuhan primer yang harus dipenuhi bagi

\footnotetext{
${ }^{2}$ QS an-Nisa' (4): 21; al-Ahzab (33): 7

${ }^{3}$ Ibn Rusyd, Bidayah al-Mujtahid wa Nihayah al-Muqtashid, (Mesir: Syirkah Maktabah wa Mathba'ah Mushthafa al-Babi al-Halabi wa Awladuh, Cet.III, 1379H./ 1960M.), Juz II, hal. 2.
} 
setiap pasangan suami istri yang berelasi, sehingga hak-hak masing-masing dijamin secara hukum.

\section{B. Memaknai Ulang Hakikat Perkawinan}

Pernikahan tidak harus dimaknai sebagai 'aqd al-tamlik (perikatan kepemilikan) tetapi sebagai 'aqd al-ibahah yakni kontrak kebolehan, dalam hal ini, menggunakan /membolehkan penggunaan alat reproduksi perempuan yang sebelumnya diharamkan. Konsep pernikahan yang dipahami sebagai 'aqd altamlik (perikatan kepemilikian), ${ }^{4}$ berimplikasi bahwa perempuan/isteri adalah milik suami seutuhnya. Dalam konteks ini, istri tidak memiliki posisi tawar (bargaining position) untuk mengatur atau mengurus dirinya sendiri. Hal ini, karena ketaatan mutlak yang diinginkan oleh konsep pernikahan 'aqd al-tamlik, tidak memberikan ruang bagi isteri untuk menolak atau sekedar mempertimbangkan tentang apa yang seharusnya atau yang tidak seharusnya dilakukan olehnya. Implikasi lebih jauh dari konsep ini adalah rentan terjadinya kekerasan dalam rumah tanga (KDRT), yang dalam konteks ini dilakukan oleh suami terhadap isterinya. Sedangkan konsep pernikahan yang dipahami sebagai 'aqd al-ibahah, memungkinkan istri memiliki posisi tawar (bargaining position) untuk melakukan pilihan-pilihan perbuatan tertentu sesuai dengan keinginannya dengan menjaga kehormatan dan proposrsinya sebagai seorang isteri. ${ }^{5}$ Hal ini karena, dalam konsep ini, perempuan/isteri memiliki otoritas dan penguasaan atas dirinya, sehingga ia leluasa mengekspresikan dirinya dalam mengarungi bahtera pernikahan, termasuk dalam hal yang spesifik, hubungan seksual.

Tujuan pernikahan adalah untuk memperoleh kebahagiaan dan kesejahteraan lahir dan batin menuju kebahagiaan dan kesejahteraan dunia dan akhirat. Pernikahan adalah tuntutan fitrah manusia, karena kasihlah landasan paling hakiki dari keberadaan manusia itu sendiri di dunia. Hidup yang paling berarti bagi manusia adalah hidup yang dihayati dalam kasih sayang Tuhan. Di

${ }^{4}$ Hussein Muhammad. Pandangan Islam Tentang Seksualitas, Makalah Seminar Gender dan Islam, Surabaya, 2004.

${ }^{5}$ Ibid. 
sinilah sebenarnya tujuan hakiki dari pernikahan, yang diderivasi ke dalam beberapa tujuan, antara lain untuk menikmati hubungan seksual, melakukan regenerasi dan sebagainya.

Di dalam Kompilasi Hukum Islam (KHI) tidak didefinisikan secara rinci pengertian pernikahan. Sebagaimana disebutkan pada pasal 12 Bab II, KHI mengambil definisi sebagaimana yang ditunjuk al-Qur'an bahwa pernikahan merupakan akad yang sangat kuat atau mitsaqan ghalidzan, untuk mentaati perintah Allah dan melaksanakannya merupakan ibadah. ${ }^{6}$

Ketika pernikahan dimaknai sebagai ikatan yang demikian kuat dan mendalam (mitsaqan ghaliidzan), maka ia memiliki makna yang demikian kuat, baik hakiki maupun implikasinya. Namun permasalahnnya adalah bahwa ketentuan dari pernikahan, masih banyak yang bias gender sehingga mereduksi keagungan pernikahan itu sendiri. Dalam konteks ini misalnya dapat dilihat konsep peminangan yang harus dilakukan pihak laki-laki (pasal 11-12), wali yang disyaratkan laki-laki (pasal 20), saksi yang juga laki-laki (pasal 25), perjanjian perkawinan (pasal 45), dan beristeri lebih dari satu orang (pasal 55). ${ }^{7}$ Berdasarkan pada butir-butir pasal di atas, terdapat reduksi-reduksi makna hakiki perkawinan. Hal ini selanjutnya berimplikasi terhadap bangunan rumah tangga, yang dalam banyak kasus juga dapat menimbulkan kekerasan dalam rumah tangga karena adanya dominasi satu pihak atas pihak lain.

\footnotetext{
${ }^{6}$ QS. Al-Nisa':21. Pengertian ini pula yang diadopsi oleh pasal 12 bab II Kompilasi Hukum Islam (KHI)

${ }^{7}$ Kompilasi Hukum Islam (KHI) ditetapkan berdasarkan Instruksi Presiden RI Nomor 1 tahun 1991, yang ditindaklanjuti dengan Keputusan menteri Agama RI Nomor 154 tahun 1991.
} 


\section{Perkawinan Sebagai Kontrol Sosial Patriarkhi Terhadap Perempuan}

Kendati patriarkhi memberikan kontribusi besar bagi pelanggengan dominasi laki-laki atas perempuan, sebenarnya sistem ini juga membatasi ruang gerak laki-laki, yang "dipaksa" selalu harus tampil rasional, maskulin dan petualang publik. Namun demikian, dibanding "penderitaan" laki-laki yang diakibatkan oleh ideologi ini, keuntungan yang dirasakan laki-laki lebih besar. Pada saat yang sama, ideologi ini sama sekali tidak memberikan keuntungan bagi perempuan. Sebaliknya, ia diciptakan untuk melakukan kontrol sosial terhadap perempuan, baik kontrol terhadap tubuh maupun peran sosial perempuan. Warisan keagamaan kuno hingga modern, tampaknya juga memberikan kotribusi besar bagi pengontrolan tubuh dan sosial perempuan tersebut.

Sistem teologi agama kuno yang menggambarkan sosok tuhan-tuhan yang banyak, kemudian diseleksi pada gambaran-gambaran tuhan yang berpengaruh, hingga kepercayaan monotheisme, memberikan gambaran Tuhan sebagai sosok bapak yang perkasa, sebagaimana dalam sistem teologi Kristiani misalnya, merupakan proses sekunderisasi perempuan.

Secara historis, munculnya ideologi patriarkhi berasal dari mesopotamia Kuno pada zaman neolitikum, seoring dengan munculnya negara-negara kota. Bahkan menurut para femnis, munculnya hegemoni laki-laki atas perempuan, sesunguhnya terjadi jauh sebelum era neolitikum yang menandai lahirnya negaranegara kota tersebut.

Antara tahun 3500-3000 SM, di Mesopatamia bermunculan negara-negara kota. Kondisi ini mengakibatkan adanya peranan militer dan politik terhadap hegemoni. Hal ini memperkuat dominasi laki-laki atas perempuan, sehingga menimbulkan adanya stratifikasi sosial pada masyarakat. Sistem keluarga patriarkhi yang memastikan penyampaian warisan dari ayah kepada anak lakilaki, dan pengontrolan seksualitas perepmuan menjadi melembaga. Hal ini kemudian terekam ke dalam hukum dan kemudian mendapat legitimasi dan dukungan dari institusi politik maupun negara. 
Dalam konteks di atas, seksualitas perempuan menjadi aset dan kekayaan laki-laki, pertama milik ayah dan kedua milik suami. Kesucian seksualitas perempuan memperoleh nilai ekonomi, yang bisa dijadikan modal tawar menawar. Tampaknya budaya seperti ini juga terserap dalam praktik keagamaan di dunia Islam. Uang jemputan dalam kasus peminangan perempuan Makassar atau perempuan Aceh, merupakan contoh konkritnya, di mana harga perawan ditentukan oleh status sosial ayah-nya.

Kemunculan negara-negara kota pada zaman Mesopotamia Kuno, menyebabkan ditinggalkannya perempuan sebagai pekerja. Akibatnya kondisi ini semakin menjauhkan perempuan dalam "petualangan" publik, yang bisa dihargai secara ekonomis. Dengan demikian, pengisolasian perempuan dari bursa kerja negara-negara kota, mengurangi kontribusi mereka dalam akses ekonomi. Kondisi ini semakin memperkuat sekunderisasi perempuan, bahkan lebih jauh merendahkan status perempuan.

Kondisi pengotrolan dan pembatasan gerak perempuan dalam konteks masyarakat Mesopotamian, semakin ditopang oleh aturam negara, berupa Undang-undang Hamurabi (1750 SM), yang dibuat atas nama dewa Perang, Marduk. Sekali lagi perlu dipahami bahwa peperangan merupakan simbol hegemonik dari petualangan laki-laki.

Kendati dalam banyak hal merugikan perempuan, kode Hammurabi masih memberikan sedikit hak kepada perempuan. Misalnya dikatakan bahwa bagi laki-laki yang menceraikan isteri-isterinya, diharuskan membayar ganti rugi. Aturan ini berbeda dengan Undang-undang Assyiria (1200 SM), yang membatalkan hak-hak perempuan sebagai ibu. Hak itu diberikan kepada suami, yang belum tentu ia berikan kepada isterinya yag dicerai. Misalnya dinyatakan dalam ayat 183, bahwa bila laki-laki menceraikan isterinya, ia bisa memberikan sesuatu kepada isterinya bila ia mau, jika ia tidak mau memberikan sesuatu kepada isterinya, maka isterinya pergi dengan tangan kosong. ${ }^{8}$

8 Fatmagul Berktay," Ciri Khusus Patrarkhi: Kontrol Sosial terhadap Tubuh Perempuan", dalam Suralaga\&Rosatria (ed.), Perempuan: dari Mitos, 1-39. 
Dalam konteks Mesopotamia kuno, sumber kekuatan dan kekuasaan berada di tangan ayah dan suami. Perempuan dan anak-anak harus patuh kepada kekuasaan mutlak mereka. Dalam Undang-undang Hamurabi dinyatakan bahwa kepala keluarga berhak mengatur perkawinan ank-anaknya. Ia bisa mengirim anak-anak perempuannya ke candi untuk menjadi biarawati. Ia bisa menggadaikan istri dan anak-anaknya untuk membayar hutang-hutangnya.

Tidak berbeda dengan Hamurabi, Assyiria juga menyatakan bahwa bila seorang suami memperkosa perempuan lain, maka perbuatan itu akan mengotori istrinya. Karena itu ia harus mnceraikan istrinya.jika terjadi pemerkosaan atas gadis oleh laki-laki lajang, maka laki-laki tersebut harus membayar harga gadis tersebut kepada ayahnya dan mengawininya. Dengan demikian, perempuan sama sekali tidak memiliki otonomi dan independensi atas dirinya.

\section{Perkawinan dan Simbol Kontrol Sosial}

Penggunaan cadar bagi perempuan terutama di kawasan jazirah Arab, terpengaruh oleh Undang-undang Asyiria. Dalam undang-undang tersebut, dibedakan secara jelas perempuan yang berhak dan tidak berhak menggunakan cadar. Cadar merupakan simbol bagi kesucian dan keperawanan perempuan. Simbol ini juga menjadi pertanda adanya perempuan yang berada di bawah perlindungan laki-laki, dan perempuan "bebas" yang bisa menjadi "mangsa" seksual bagi siapapun.

Dalam konteks masyarakat arab, budaya ini digunakan untuk membedakan antara hurrah dan 'amat. Hurrah adalah para perempuan terhormat yang hidupnya di bawah perlindungan laki-laki terhormat. Sedangkan 'amat merupakan perempuan-perempuan pekerja seksual, yang tidak memiliki pelindung seorang laki-laki. Perintah berjilbab bagi para perempuan, juga terkait dengan budaya masyarakat Arab yang sebelumnya tidak ada perbedaan antara hurrah dan amat tersebut. 
Menurut Lerner, sebagaimana dikutip Fatmagul Bertaky ${ }^{9}$, menyatakan bahwa dengan demikian, cadar tidak saja merupakan simbol kelas atas, tetapi lebih penting lagi, ia merupakan simbol yang membantu membedakan antara perempuan yang bisa dinikmati oleh banyak laki-laki, dengan perempuan yang hanya bisa dinikmati oleh satu laki-laki dan hidup berada di bawah perlindungannya. ${ }^{10}$

Dengan demikian, pemakaian cadar dan kerudung atau penutup kepala, sesungguhnya tidak saja merupakan tradisi Islam, tetapi telah ada jauh sebelum Islam datang. Dalam tardisi Kristen, pemakaian kerudung atau penuup kepala telah dilakukan oleh St. Paul untuk membangun satu bagian pelembagaan Kristen. Dalam agama Yahudi, Yunani dan Byzantium yang berada dalam peradaban Laut Tengah bagian Timur, cadar melibatkan arti sosial yang semakin kompleks. Namun demikian, dalam tardisi agama-agama dunia, tradisi cadar atau kerudung dan penutup kepala, lebih terasa khas dalam trdisi Islam dibanding dalam tradisi agama-agama selainnya.

Pada abad pertama Masehi, satu-satunya wilayah efektif bagi perempuan Yahudi adalah pada lingkungan keluarga. Pembatasan peran perempuan diasosiasikan dengan tradisi perkawinan di era itu. Kekuasaan seorang ayah atas anak perempuan mereka dan kekuasaan suami atas siterinya, demikian luar biasa. Semua hukum tentang perkawinan, kewarisan dan perceraian, kemudian dikonstruksi dengan berpihak kepada kaum lai-laki. Sedikit sekali peraturan hukum yang menetralkan atau mengimbangi kontrol dan kekuasaan ayah dan suami. Seseorang bisa menyebutkan bahwa "uang cerai" yang harus dibayarkan oleh suami kepada isterinya yang diceraikan. Namun di sisi lain anak perempuannya yang belum dikawinkan, memiliki hak untuk mengikuti ayahnya. Dengan demikian, sekali lagi, nilai ekonomis anak perempuan, berpulang kepada ayahnya.

${ }^{9}$ Ibid.

${ }^{10}$ Ibid. 
Dengan sejumlah elaborasi pada beberapa aspek, tampaknya hukum Islam juga mengadaptasi atau minimal dipengaruhi oleh agama Yahudi dalam hal perkawinan, perceraian dan hak waris. Misalnya dalam Perjanjian Lama dinyatakan bahwa ibu patut mendapatkan penghormatan sama dengan penghormatan terhadap ayah. Bahkan menurut Mishnah dan Talmud, dua kitab pegangan komunitas Yahudi, perempuan juga memiliki hak untuk menikmati kesenangan seksual. Demikian juga dalam soal kewarisan. Perempuan Yahudi memiliki hak untuk mendapatkan harta kekayaan, dan ia diberi hak untuk memiliki bagian dari warisannya, meskipun prioritasnya diberikan kepada anak laki-laki.

Dalam tradisi agam-agama monoteisme, terdapat praktik keagamaan yang meminggirkan perempuan, yang tampaknya juga diwariskan secara turuntemurun. Dalam konteks Yahudi misanya, kendati pada awalnya perempuan diberi kesempatan untuk melakukan peribadatan pada kuil yang sama dengan laki-laki, pada tahap berikutya hak tersebut dirampas. Mereka hanya diberikan hak untuk melakukan peribadatan dalam kuil yang terpisah dengan laki-laki. Paraktik semacam ini telah ada di era pemerintahan Trajan di Yerussalem, sejak abad $2 \mathrm{M}$.

Warisan peribadatan semacam ini, juga bisa ditemukan dalam tradisi Kristiani. Perempuan dilarang berbicara di gereja. St. Paul menunjuk tentang hal ini dalam surat pertamanya kepada Corinthians: "Biarkan perempuan-perempuan kamu tetap diam ketika mereka berada di gereja, karena mereka tidak diizinkan berbicara; mereka diperintah untuk patuh dan begitu pula hukum memerintah mereka untuk patuh. Bila mereka ingin belajar apasaja, biarkan mereka meminta atau menanyakannya kepada suami mereka. Adalah memalukan bagi perempuan untuk berbicara di gereja (Corinthians, 14: 34-35).

Perintah yang terdapat dalam naskah Corinthians yang diperoleh dari St Paul ini equivalen dengan ide bahwa laki-laki adalah pemimpin perempuan. Kontrol atas perempuan yang sangat dikenal dengan tubuh merupakan analog mengenai kontrol terhadap gereja yang merupakan tubuh Kristus. 
Larangan bagi perempuan untuk berbicara di gereja, dipahami dari bab 15 Kitab Leviticus, yang menyebutkan bahwa pendeta yang melakukan sesajian atau persembahan kepada Tuhan harus dalam keadaan bersih. Dalam konteks ini, perempuan dianggap tidak bersih ketika mengalami menstruasi. Karena itu, perempuan dilarang berbicara di gereja karena dengan "kekotorannaya" berarti ia tidak bisa melaksanakan kewajiban agamaya. Lagi-lagi, dalam ritual-pun, perempuan dianggap tidak memiliki porsi yang sama dengan laki-laki, ia dianggap berkurang agamanya dari laki-laki. Tampaknya kepercayaan akan kekurangan agama perempuan juga terilfiltrasi dan tertransfer ke dalam tradisi Islam. Bahkan dalam salah satu Hadits Nabi, dinyatakan bahwa perempuan memiliki dua kekurangan, yakni kekurangan pada akal dan agamanya. ${ }^{11}$

Tradisi agama-agama yang berakar pada tradisi Mesopatmia Kuno, yang menginfiltrasi pemikiran agama Yahudi, Kristen dan Islam, terdapat mekanisme pelembagaan dan penetapan patriarkhi yang mengontrol tubuh perempuan. Hal ini tentu saja berimplikasi pada kontrol sosial-budaya terhadap peran perempuan.

Margareth Mead, ${ }^{12}$ menyatakan bahwa dikhotomi seka ada pada setiap masyarakat. Perbedaan biologis antara perempuan dan laki-laki, tidak secara otomatis menciptakan ketidaksetaraan di antara keduanya, yang oleh Francoise Heritier dinyatakan bahwa implikasi ketidaksetaraan dimaksud meresap ke semua aspek kehidupan.

Senada dengan tesis di atas, pendapat Aristoteles bahwa perempuan adalah aki-laki yang kurang, dan kepercayaan bahwa Hawa bertanggung jawab atas dosa warisan dan pengusiran Adam dari Surga, juga semakin mendukung pelembagaan patriarkhi, metafora dasar dan simbol-simbol peradaban bahwa peremuan lebih redah dari laki-laki. Implikasinya lebih jauh adalah, munculnya dua konsep mengenai manusia, yakni: konsep laki-laki dan konsep perempuan yang secara hirarkhi berbeda bentuk, fungsi dan potensinya. Dalam konteks

${ }^{11}$ Lihat Masdar Farid Mas'udi, Islam dan Hak-hak Reproduksi Perempuan (Bandung: Mizan, 2001), 42.

${ }^{12}$ Fatmagul Berktay, "Dikhotomi Antara Jiwa dan Tubuh: Masalah Polarisasi di dalam Diri Manusia", dalam Suralaga\&Rosatria (ed), Perempuan: Dari Mitos, 42 
iniulah, tubuh yang tidak saja dianggap sebagai teks kebudayaan, merupakan fokus kontrol sosial yang praktis, sebagamana didefinisikan oleh Bourdeu dan Foucoult.

\section{E. Kesimpulan}

Peran laki-laki dan perepuan secara sosial, baik dalam kehidupan domestik maupun dalam ranah kehiduan pulik, lebih ditentukan oleh teori nurture, bukan teori nature. Konstruksi ini telah ada sejak 3500 SM, sejak lahirnya Kode Hamurabi dan Asyiria tentang ideologi patriarkhi. Konstruksi ini kemudian diadaptasi oleh ara filosuf Yunani dalam pemikiran filsafat mereka, seperti Plato yang melihat dunia sebagai proses oposisi kembar yang tiada henti, Aristoteles yang mengandaikan dualisme hirarkhi, serta Philo yang mencari legitimasi pemikirannya pada naskah Perjanjian Lama, seperti cerita Adam dan Hawa yang diinterpretasikan sebagai cara menyimbolkan sesuatu yang mengacu kepada realitas kosmik. Sistem filsafat tentang peran laki-laki dan perempuan ini semakin dikokohkan dalam metafisika Barat, yang dapat dilihat pada konstruksi hstoris bahwa posisi laki-laki dan perempuan merupakan hasil langsung dari kolaborasi dari tiga konsep metafisika, yakni: identitas, dikhotomi dan kodrat.

Aturan normatif tentang perkawinan dalam rumusan fiqih yang kemudian diadaptasi oleh KHI, juga dikonstruksi oleh para ulama dan fuqaha dengan setting sosio-kultural dan politik yang bernuansa bias gender. Pemahaman para ulama tentang aturan perkawinan dan diadaptasi oleh KHI, berimplikasi pada pemahaman dan praktik kehidupan perkawinan dalam masyarakat.

Pola relasi suami-isteri yang a simetris, bisa menumbuhkan sikap dominasi dan kepenguasaan satu pihak atas eksistensi pihak lain serta pendefinisian laki-laki yang lebih tinggi derajatnya dibanding perempuan, jika tidak dipahami secara proporsional juga bisa mengakibatan adanya praktikpraktik ketidakadilan gender, berupa marjinalisasi, subordinasi, bahkan kekerasan. 


\section{BIBLIOGRAFI}

Al-Jaziri, Abdurrahman. Al-Fiqh 'ala Madzahib al-Arba'ah. Mesir: al-Maktabah alTijariyyah al-Kubra, Juz 4, tth.

Al-Qur'an dan Terjemahannya. Jakarta: Depag RI tahun 1990.

Aristotels, Politics, Remzi Publishing House, Istambul, 1983.

Berktay, Fatmagul," Ciri Khusus Patrarkhi: Kontrol Sosial Terhadap Tubuh Perempuan", dalam Suralaga\&Rosatria (ed.), Perempuan: Dari Mitos ke Realitas. Jakarta: PSW UIN Jakarta - McGill-ICIHEP, 2002, 1-39.

-"Dikhotomi Antara Jiwa dan Tubuh: Masalah Polarisasi di dalam Diri Manusia", dalam Suralaga\&Rosatria (ed), Perempuan: Dari Mitos ke Realitas. Jakarta: PSW UIN Jakarta - McGill-ICIHEP, 2002, 41-56.

Bhasin, Kamla dan Nighat Said Khan. Persoalan Pokok mengenai Feminisme dan Relevansinya, Jakarta: Gramedia Pustaka Utama, 1995.

Dewantoro M. Hajar, Rekonstruksi Fiqh Perempuan dalam Peradaban Masyarakat Modern, Yogyakarta: Pustaka Ababil, 1996.

Fakih, Mansour, Posisi Kaum Perempuan dalam Islam Tinjauan dari Analisis Gender. Dalam Membincang Feminisme Diskursus Gender Perspektif Islam. Surabaya: Risalah Gusti, 1996.

Fatmagul Berktay," Ciri Khusus Patrarkhi: Kontrol Sosial terhadap Tubuh Perempuan", dalam Suralaga\&Rosatria (ed.), Perempuan: dari Mitos. ke Realitas. Jakarta: PSW UIN Jakarta - McGill-ICIHEP, 2002.

_-"Dikhotomi Antara Jiwa dan Tubuh: Masalah Polarisasi di dalam Diri Manusia", dalam Suralaga\&Rosatria (ed), Perempuan: Dari Mitos, ke Realitas. Jakarta: PSW UIN Jakarta - McGill-ICIHEP, 2002.

Hadar, Ivan A. "Feminisme, Feminis Laki-laki dan Wacana Gender Dalam Upaya Pengembangan Masyarakat", dalam Nur Iman Subono (ed)., Feminis Lakilaki: Solusi Atau Persoalan?. Jakarta: Yayasan Jurnal Perempuan- The Japan Foundation, 2001.

Hidle Hein, Liberating Pjhilisophy: Anm End to the Dichotomy of Spirit and matter," eds. Ann Gary dan Marlyn Persall, Women, Knowledge and Reality, London: Unwin Hyman, 1989. 
Ivan A. Hadar, Feminisme, Feminis Laki-laki dan Wacana Gender Dalam Upaya Pengembangan Masyarakat, dalam nur Iman Subono (peny.), Feminis Laki-laki: Solusi atau Persoalan? Jakarta: Yayasan Jurnal Perempuan-The Japan Foundation, 2001, 93-111.

Ibn Rusyd, Bidayah al-Mujtahid wa Nihayah al-Muqtashid.Mesir: Syirkah Maktabah wa Mathba'ah Mushthafa al-Babi al-Halabi wa Awladuh, Cet.III, 1379H./ 1960M, Juz II.

Hussein Muhammad. Pandangan Islam Tentang Seksualitas, Makalah Seminar Gender dan Islam, Surabaya, 2004.

Mas'udi, Masdar Farid. Islam dan Hak- hak Reproduksi Perempuan. Bandung: Mizan, 1999.

Mulia, Siti Musdah. Menuju Undang-undang Perkawinan Yang Adil. Makalah Seminar Nasional dan Lokakarya "Amandemen Undang-undang Perkawinan dan Keluarga untuk Melindungi Hak-hak Perempuan dan Anak”, PSW UIN Yogyakarta, 13-16 Juli 2006.

Munti, Ratna Batara. Perempuan Sebagai Kepala Rumah Tangga. Jakarta: Lembaga Kajian Agama dan Gender, 1999.

Sumbulah, Umi. Fiqih Munakahat dan Implikasinya dalam Fiqih Mu'asyarah: Sekelumit Analisis Gender. Makalah Seminar dan Simulasi Pernikahan BEM Fakultas Syariah UIN Malang, 2004.

Suralaga, Fadhilah \& Rosatria, Eri (ed.), Perempuan : Dari Mitos ke Realitas. Jakarta: PSW UIN Jakarta - McGill-ICIHEP, 2002.

Umar, Nasaruddin, Argumen Kesetaraan Gender, Bandung: Mizan, 1999.

Wardhana, Veven Sp. " Puanografi dan Media: Yang Bukan perempuan (Tak) Ambil Bagian”, dalam Nur Iman Subono, Feminis Laki-laki: Solusi Atau Persoalan. Jakarta: Yayasan Jurnal Perempuan- The Japan Foundation, 2001. 